\title{
Educational Situation in the Prefecture of Elbasan in the Years of the Albanian Parliamentary Republic 1925-1928
}

Rudina Mita

Prof.Asoc. Dr. ,University: "Aleksander Xhuvani", Elbasan-Albania

Enkelejda Balla

Msc., University: "Aleksander Xhuvani", Elbasan - Albania

\section{Abstract}

Our study aims to highlight one of the most important aspects of the Elbasan Prefecture, the educational aspect during 1925-1928. In order to analyze the education during the mentioned years, the attention and tradition and educational environment of Elbasan had to be considered during the earlier periods since the Ottoman conquest. The historical educational experience culminated in the opening of the "Normal" School in 1909, the first high school that trained and prepared teachers' teachers for the Albanian language; experience and educational achievements of 1920-1924, years in which education was given priority on the basis of the principles of massivization, nationalization, secularization and unification. Given this educational tradition even during the years we have been studying, the Prefecture of Elbasan has taken important steps in Education. In the educational development of Elbasan, the intellectual elite and educated teachers in the West, Austria and Italy, etc., who together with their scientific formation brought together the Elbasan City and the educational experience of the countries of who came. Problems, the level of primary and secondary education, the difficulties in the education system, the lack of school buildings and funds for opening and maintaining them, the education of women in special schools by males, and the charitable activity of elbasanas in terms of education, the school of education of the children of the region are some of the aspects that we have included in our study. Through this paper, the educational aspect of 1925-1928, a little handled in the context of the local history of the Elbasan Prefecture, sheds light on. ${ }^{1}$

Keywords: education, school, inspector of education, general director of education, "normal" school, plotor, student

\footnotetext{
${ }^{1}$ The used literature is based on documents of the Central State Archives of the Republic of Albania, local historiography, written print and memoirs of memorials.
} 


\section{Introduction}

\section{Educational Situation in Albania to the eve of Lushnja Congress}

In Albania, the level of education left to be desired for a number of factors, which had influenced its deep backwardness. The five centuries-long Ottoman rule had left its repressive trace on the education of Albanians in their language and the opening of Albanian schools. Despite the efforts made by the Albanian intellectual elite in and out of the country in this regard, the educational aspect was very severe. A large part of the existing schools in Albania were close to religious institutions and teaching was done in a foreign language. Illiteracy included $90 \%$ of Albanian society. In the course of the efforts of the Albanian intellectuals, several Albanian elementary schools and a high school in Elbasan were opened in 1909, called the "Normale"1 School, which prepared teachers' cadres for the Albanian schools in the country. This school with the pressures of the Ottoman state and the financial difficulties (financed by the Albanian people) passed several stages of closure and reopening again. The situation continued the same in the years 1912-1920. In the early 1920's, after the Lushnja National Congress, education had some growth, albeit with slow steps, guided by orienting policies in the field of education aimed at massaging, nationalizing, secularizing and unifying education. Many individuals in the country and Elbasan were educated in Western countries, making up the elite basis for generations of education in Albanian schools.

\section{The educational state of Elbasan in the years 1920-1924}

In terms of education, Elbasan was one of the territories of Albania, which had demonstrated and had given the clearest example that a country's progress could only be achieved on the basis of a nation's education. Despite the efforts made, over $80 \%$ of the population in this area continued to be illiterate. If we make a retrospective of the educational level on the years 1920-1924 show that this area had to develop education in two levels, both primary and secondary. The Normal School until 1924 consisted of 4 classes: 1 cookie and 3 normal, as the school expanded, the number of students grew up, returning to a boarding school. On October 21, 1923, for the first time in Elbasan, near the Normale school, the training school that depended on it was opened. Teachers who served as pedagogical staff who helped and contributed to this school were: Sul Harri, Karl Ljarja, Ahmet Duhanxhiu and Fadil Gurmani turning this school back to: "... the first fire that devised a qualitative increase of didactic nationally

\footnotetext{
1 The "Normal" school was a school that was opened at the time of the Ottoman conquest with the contributions of the Albanians, and keeping it alive and its functioning was carried out not with the teaching staff's salary from the Ottoman Empire but with the money donated by itself Albanians
} 
in Albania. ${ }^{11}$ During the first year of its opening, the Exerciser had 1 class with 18 students. An important event in 1924 was the emergence of this school of the first 15 graduates, educated in a full 4-year cycle. In the years 1920-1924, the number of students in the Elbasan Prefecture ${ }^{2}$ was over 10,100, while the number of teachers in 59. Of these 59 teachers, 53 teachers were male and 6 were female. At three levels, only 6 students had completed universities in Western countries, 31 students had finished normal school, 34 students and students were studying in Europe at universities in Italy, Austria and Yugoslavia.

\section{Education in Elbasan Prefecture in 1925-1928}

At the beginning of 1925, the Albanian state entered the Republican stage of government. In the light of the financial difficulties created during 1924, in the six months of June's June Revolution (June 1924 - December 1924), the educational situation was severe. ${ }^{3}$ Teachers had months without receiving salaries from the state and were not the only ones in this regard. The policy of the Albanian Republican Government (1925-1928) focused on the development of education, the increase of the number of Albanian (local) schools and the strengthening of the role of state education compared to the foreign schools that existed in the country.

During this period all over the country in Elbasan, besides the growth of the role of the state in this sector, attention was focused on the important role that would be played by the aids provided by the people for building the educational infrastructure. In orienting policies to the government this influence had left an important place in terms of shortages and hardships that were evidently visible in the Albanian state budget. The people's aid consisted in voluntary collection of money for building school buildings, aid for the books and the necessary tools for poor children, so that they could be educated like others by facing the costs of education, offering their homes for school, or wealth donation for help and assistance in education in the area. In each Prefecture there were Education Inspectors who were the spokespersons of the General Directorate of Education. ${ }^{4}$ The role of the Education Inspector was to expand the education in the areas, identify obstacles, difficulties, deficiencies, transmit them to local or governmental bodies, meet the needs of the education staff and follow up governmental policies in the field of education for massive and inclusive education. Albanian society in it etc.

\footnotetext{
${ }^{1}$ Abdyl Paralloi, "The Contribution of the Exercise School to the Albanian Pedagogical-Didactic Thought, taken from" Normality in Tradition ", Elbasan 1995, pages 78-79

2 The Elbasan Prefecture consisted of Elbasan District, Sub-Prefectures: Peqin e Gramsh

3 Our Note: The difficult financial situation was due to the lack of knowledge of the government of Fan Noli, the government emerged from the Revolution of June 1924, by internationals due to the manner and form chosen by the liberal-democrats to come to power, by dropping a government out of the vote by the legitimate elections of December 1923

${ }^{4}$ From 1925 to 1927 did not work the Ministry of Education but the General Directorate of Education
} 
In the Elbasan Prefecture the education sector was controlled by the Inspector and district teachers. In 1925 Elbasan's education inspector was Fot Papajani. Difficulties in education in the area of Elbasan were numerous, but also factors and inhibitory factors as well. Often, the intervention of the Prefecture Elbasan was required for the solution of unfavorable and impossible situations for the Institution of Education Inspectorate, for the solution of the created situation or cramp. According to an information provided by the Education Inspectorate to the Prefecture of Elbasan, we are aware of the lack of school buildings in the villages surrounding Shijon, Karakullak, Reçan, Fikas, Petresh, and the difficulties for the Old Testament family near Shijon for finding a school building. The inspector asked the Prefecture to command elders to resolve this problem. ${ }^{1}$

One of the tasks of the Education Inspector was the inspection of schools. In October 1925, the Inspectorate of Education informed that it had inspected the schools of the villages of the Cermenika Districts, Librazhd of Quka and the school of Shinkolli in the city, also conveyed the information that Elbasan was opened and the night school in which they attended the lesson about 60 students. ${ }^{2}$

Although some progress has been made in some areas in Elbasan, great difficulties have arisen in the sub-prefectures of Elbasan, especially in the Gramsh Prefecture, where: "Education is held in all branches, schools are rare, in places where pupils continue the poor education." 3 The picture in this sub-prefecture forced the Prefect of Elbasan, Izet Dibra, to order the Prefecture Education Inspector to take the necessary measures to change the situation. In the report to the Inspectorate it was emphasized that "... education is a weaker pretext ... this weakness of how it stems, whether the lack of care or lack of teachers, or not the continuation of knowledge in schools ... "4 According to the Secretary of the Sub-Prefecture Gramsh Petar Xhuvani stressed one of the difficulties created in education and the functioning of schools was due to the lack of timely appointment of teachers at the Gramsh school and the Grabova and Christina schools. The intervention of the Education Inspector made possible the appointment of teachers, a measure which influenced the start-up and functioning of the schools normally. ${ }^{5}$ Another factor for the difficult state of education in the sub-prefecture of Gramsh, according to the Education Inspector, was budget constraints that prevented the opening of new schools in this Subprefecture. ${ }^{6}$

In February 1926, in the Elbasan district, on the basis of instructions from the General Directorate of Education on the implementation of the Law on the Establishment of School Commissions, Elbasan's Education Inspectorate asked the Prefecture of

\footnotetext{
1 Central Archive. of R. Al., F. 271-Elbasan Prefecture, D. 161, page 1, 1925

${ }^{2}$ Central Archive. of R. Al., F. 271-Elbasan Prefecture, D. 194, page 2, 1925

${ }^{3}$ Central Archive. of R. Al., F. 271-Elbasan Prefecture, D. 152, page 3, 1927

${ }^{4}$ Central Archive. of R. Al., F. 271-Elbasan Prefecture, D. 161, page 5, 1925

5 Central Archive. of R. Al., F. 271-Elbasan Prefecture, D. 161, page 6, 1925

${ }^{6}$ Central Archive. of R. Al., F. 271-Elbasan Prefecture, D. 161, page 9, 1925
} 
Elbasan to order the establishment of the School Committee as in the Prefecture and Sub-Prefectures Peqin of Gramsh and proposed some teachers to be included in these commissions. The Inspectorate had nominated as secretary of the Elbasan Commissioner Maliq Mullahollin, the Peqin Commission Director of the Center School, and Gramsh as the secretary was the teacher of that Sub-Prefecture. ${ }^{1}$ The Elbasan Education Commission was chaired by the Mayor and consisted of three members: Taqi Buda, Emin Haxhi Ademi and Kamber Gjergjani. ${ }^{2}$ The activity of the Education Councils in the Elbasan Prefecture was diverse and aimed at not only highlighting the problems that arise in the localities but also taking concrete measures for the delivery of education in the area where it operated. The Elbasan Educational Council reviewed numerous problems encountered in education in the area it covered, and related to the difficulties created by pupils in attending schools and the lack of staff in some schools. At its meeting on December 14, 1927, the Education Council of Elbasan under the chairmanship of Prefect Murat Podgorica and with its members ${ }^{3}$ reviewed the problems of the School Directorate for the regular non-attendance of 10 pupils of this school, or the complain of the Homeland of Martha's the continuation of the teaching of that village Sabri Skile. ${ }^{4}$ From the measures taken by the Educational Council, the school of Martanesh had started functioning on December 26, 1926: "Zdrajshë schools have remained locked without teachers, that of Martanesh continues on a regular basis."

To give a detailed picture of the educational situation in the Prefecture of Elbasan, we have relied on several documentary sources, which although state sources of information provide alternative results with regard to schools, teachers and the number of pupils in them.

In the District of Elbasan the education situation, teachers 'and students', schools ${ }^{6}$ for each school in 1927 were as follows: Baltës: Ali Tola (30), Bashant: Mustafa Gjata

\footnotetext{
1 Central Archive. of R.Al., F. 271-Prefecture of Elbasan, D. 161, p. 3, 1926

2 Central Archive. of R. Al., F. 271-Prefecture of Elbasan, D. 161, p. 10, 1926

${ }^{3}$ Members: Deputy Mayor Haxhi Ali, Commissar of the Gendarmerie Llesh Mirashi, Director of the Planned School of Plotore Fot Papajani, and members of the Commission Emin Haxhi Ademi, Taqi Buda, Ali Çaushi
}

${ }^{4}$ Central Archive. of R. Al., F. 271-Elbasan Prefecture, D. 116, page 2, 1927

5 Central Archive. R. Al., F. 271-Elbasan Prefecture, D. 42, page 37, 1927

6 Our Note: Schools presented are in the Elbasan District. According to data based on documentary information $(\mathrm{AQSH})$, there were 67 schools together with teachers and the number of students. The school concept according to the merciless data implies their existence in the villages, where in the concept of a school could be understood the existence of a class, with teachers and students. Many of these villages, despite the fact that they were taught in their village, could have had their own school center in another village (one school could include several villages). This way of creating a school (schools of some schools) as an inclusion criterion had a close relationship between them, the administrative organization and so on. Therefore, the 67 villages and schools in them were in total in 19 schools in the Elbasan District. We make this explanation for the facts and materials we have presented, where the total number of schools across the Elbasan Prefecture was 29 at primary, full and normal levels 
(11), Bajlil: Hysen Pajenga (39), Belshi: Sabri Skilja, Haxhire Daiu, Afërdita Caku, Ruzhdi ... (29), Bixëllenj: Ruzhdi Balliçi (68), Bradashesh: Tefta Përmeti e Kostaq Xhuvani (90), Franesh: Murteza Dylgjeri (28), Broshkë: Gani Hardhija (33), Cacabezë: Ruzhdi Hoxha (66), Cerunjë: Henrietaj Kallupi (99), Cingarë: Gani Dulja (42), Dëshiran: Xhaferr Qosja e Sanije Mitarja (120), Darëzezë: Ibrahim Gjergji (45), Dragot Dumre: Qemal Matraxhiu (92), Dragot Sulovë: Ollga Shuraja (69), Fush Buell: Kadri Qoli (40), Godolesh: Petrit Harja e Afërdita Andoni (88), Gurizi: Afërdita Caridha (45), Curani: Ibrahim Zabzuni (70), Grykësh: Xhaferr ...kja (90), Gjergjan: Afërdita...1(55), Gjinar: Perikli Bebi (57), Gjorëm: Nazmi Nixha (34), Gjyralë: Ali Domi (118), Jatesh: Hysen Hoxha (34), Jagodinë: Kadri Kashari (54), Joronisht: Refik Myftiu (27), Kajan: Myrteza Xhani (66), Korrë: Petri Caridha (36), Kozan: Ali Grada (34), Kuqan: Persefon Lazri (52), Kulej-Papër: Sulejman Karaj (42), Kuturman: Shefqet Buzo (34), Kryezjarth: Aspasija Paparisto (56), Kllojkë: Nazi Zengjenari (...), Labinot katund: Musa Shehu, Petrit Guranjaku (55), Labinot Fush: Maliq Molloholli (49), Linas: Mehmet Dardha (57), Quvhan: Merhmet Turhani (62), Llixhë: Manduh Skikuli (60), Mamël: Ryzhdi Haseqiu (33), Mollas: Hasan Tallelli (84), Mollagjesh:Skënder Haxhihyseni (74), Mëlizë: Parashqevi Dedja (42), Muriqan: Mehmet Urupi (44), Pajengë: Ymet Beqiri (33), Pakun: Mahmut Çaushi (60), Pashtresh: Myrteza Sejdini (44), Pekisht: Demir Koçi (54), Qyrkan: Xhevdet Ekmeçi (68), Rrasa: Gjusepina Fishta e Shefikat Bardhi (95), Serije: Xhemil Tela (48), Selitë: Muharrem Sarja (28), Seltar: Zigfrid Zylfi (43), Seferan: Nashifere Biçoku (54), Shalës: Alush Balza e Genc Zylfi (102), Shilbatër: Flutur Sejdini (34), Shinavlash: Mir Nosi (39), Shëngjon: Fatushe Çerma (34), Shirgjan: Hysni Minga (49), Shushicë: Ibrahim Shingjergji (86), Shelcan: Mahmut Verçani (51), Shtëpaj: Xhavid Haxhihyseni (45), Shtërmen: Krat Biba, Marianthi Biba, Burbuqe Kamami (147), Xheria: Behexhet Shopi (43), Valëshi: Abdulla Shabanaj (42), Zavalinë: Albina Deljana (59). ${ }^{2}$

In the Peqin Prefecture the educational situation, the schools that existed in 1927, the number of teachers in them, the number of pupils for this sub-prefecture was as follows: in the "Mustafa Gjinishi" City School, during 1927, 354 pupils and educational staff in consisted of: Shefki Spahiu - Director and Teacher Qemal Kaçila, Fatime Kola, Fani Kaçila, Artemis Hoxholli, Mili Kadzadej, Afërdita Mano, Mejner Voci, Meleqe Ballhysa. ${ }^{3}$ The schools of the suburbs of Peqin Prefecture, the teachers and the number of students during 1927 were presented as follows: Ballagat: Ismail Shyti 61 students, Bishqem: Hasan and Fatime Skilja 96 students; Fatishë: Miriminsa Zaimi 50 students; Galush: Salih Çala 68 pupils; Gjuzaj: Ferid Pajova 63 pupils; Gjocaj:

\footnotetext{
1 Our note: Countries with ... Are unreadable in the archive document. While the numbers entered in (...) coincide with the number of students for each of them

2 AQSH (Central Archive), F. 271, D. 70, Viti 1927, pages 3-4, My Note: The paper was in a difficult state to be decoded, perhaps some of the data may be tailored or judged to be such, because of their inability to read them

${ }^{3}$ Central Archive. of R. Al., F. 271, D. 70, Viti 1927, pages 3-4
} 
Gjenoveva Shyqja 79 students; Hasdushkaj: Nazmi Bulykbashi 61 students; Hysgjokaj: Riza Cërriku and Hatixhe Kadiu 128 students; Kazije: Ethem Bedalli 54 students; Kurtaj: Abdurrahim Ballolli 65 students; Mahmut Aga: Hasan Dilja 85 students; Mushnik: Gani Kaziu 51 students; Osmanllija: Sadik Vrijoni 56 students; Pajova: Adem Bedalli 75 students; Pojan: Isuf Çerekja 35 students; Rrogozhinë: Zyhni Ballhysa, Hasan Shingjergji 83 students, Rrostej: Hysen Lulja 36 students; Sinanballaj: Ymer Gjata 65 students; Shezë: Kadri Baltëza 65 students; Vrapi: Ymer Behluli 46 students; Vashaj: Osman Bylykbashi 58 students.

Table: Number of students and teachers in Elbasan Prefecture in $1927^{1}$

\begin{tabular}{|l|l|l|}
\hline Prefecture Elbasan & Students & Teachers \\
\hline S/P Centes & 4156 & 78 \\
\hline Librazhd & 2334 & 41 \\
\hline Peqin & 1734 & 33 \\
\hline Gramsh & 1533 & 29 \\
\hline Qyteti & 2264 & 61 \\
\hline Total & 12021 & 242 \\
\hline
\end{tabular}

So when comparing data on the number of pupils, schools and teachers in 1924, the number of pupils was 10,100 in 1927 in the Elbasan Prefecture, the number of students was 12,021, thus in five years the number was increased by 1,921 students. While the number of teachers in 1924 was 59 in 1927 was 242 an increase with 183 teachers. As we can see, education has made slow progress, while in the educational context of the number of teachers we have a significant increase in this framework. Despite the progress in the field of education according to Teki Selenica the situation in the country continued to be unsatisfactory, only $15 \%$ people are taught and $85 \%$ are illiterate ...2

Regarding the number of schools and educational staff based on Teki Selenica's data, it resulted that in the Prefecture of Elbasan during 1926-1927 there were 1 Normal school $^{3} 148$ students, ${ }^{4} 2$ full-time schools 480 students were one in Elbasan (350 pupils) and the other in Peqin (130 pupils). The total primary school in Elbasan Prefecture was 26 (1150 male students); 2 full primary schools (204 female students)

\footnotetext{
${ }^{1}$ Central Archive. of R. Al., F. 271, D. 70, Viti 1927, pages 3-4

2 Teki Selenica, "Albania in 1927", Tirana 1928, page 200

3 According to the newspaper "Telegraf", on Sunday, March 6, 1927, among other things was cited:

"After the information of the Directorate of Education, in the nine High Schools that after our Republic, learn 1270 pupils and students where the Normal School for Elbasan Boys has 200

4 Teki Selenica, the work mentioned, page LXV
} 
in total 28 school with students $1354 .{ }^{1}$ Number of staff in infant school facilities 41 men and 6 women; while staff in high school 12 men. ${ }^{2}$

In the District of Elbasan there were 19 elementary schools (466 students out of which 275 males and 191 females), 4 primary schools were in Peqin (240 pupils out of which 40 women) and 3 primary schools in Gramsh subregion (118 pupils male). According to A. Hastopallit ${ }^{3}$ Elbasani had during 1927 a population of 83,672 inhabitants, and had 29 schools if we rely on the facts above could calculate 26 elementary, 2 full and 1 normal schools.

Normal School

Normal School During the school year 1924-1925 by the Normal School as its structure there were five classrooms, one cooker and four normal classrooms, 8 teachers and Exercise two teachers and two classes. In 1925-1926 three classes, the order he kept until 1929. The Exercise School is called "... the daughter of Normales 4 ..." the first pedagogical center in Albania "Its educational activity in the didactic plan in two directions: the level of high school content and teaching methods, willingness and willingness to move on the achievements of contemporary Western pedagogy, with the goal of making it as Albanian as possible."5

In 1925-1926 Normality drew 31 normalists, and had the same number of teachers and 2 teachers of the two classroom practitioners. From 1926 until 1928, Normali regularly issued 25-30 normalists every year. During the year 1927 regarding the state of the school building we can emphasize that it was very heavy and under conditions not suitable for the development of the lesson. During August (1927), in the press of the press there were significant explanations of the Minister of Education Xhaferr Ypi, regarding some misunderstandings created by individual individuals regarding the existence or not of the funds for the building of the Normal School building by this Minister. Efforts made by the Ministry of Education for this purpose were not concrete but consisted of taking precautionary measures. During 1928, the ministry had sent the engineer and architect Soli to Elbasan to notice the situation of Normales and to determine the plan for the changes that could be made according to the possibilities.

Many elbasanas in these years carried out higher studies abroad mainly in European countries, Austria and Italy. There were a total of 12 students with scholarships. ${ }^{6}$

Education in Elbasan in 1927-1928

\footnotetext{
1 Teki Selenica, the work mentioned, page LXVII

2 Teki Selenica, the work mentioned, page LXVII

3 Official Gazette, Tirana, 6 November 1927

4 Reshit Koburja, Genc Trendi, "The Normality in Tradition", Elbasan 1995, page 90

5 Reshit Koburja, Genc Trendi, "The Normality in Tradition", Elbasan1995, pp. 87-91

${ }^{6}$ Central Archive. of R. Al., F. 271-Elbasan Prefecture, D.119, page 22, 1927
} 
In 1927 in Elbasan there was also the Women's School "Ali Agjahu", which in this year had started adjusting because of the difficult condition in which it was and the inappropriate hygienic, technical and infrastructural conditions in it. The work on arranging the Namazgjase ${ }^{1}$ Women's School continued during November 1927, and even the Elbasan Prefecture cautioned the Municipality to delay the work for its regulation.

The establishment of new schools was one of the successes of the work to improve, expand and improve the quality of education in the Elbasan Prefecture. From July to September 1927 according to the data of the Prefecture it was informed that Elbasan district was the 21st elementary school. The city school students had continued normal teaching and rebuilding the schools at the circuit and completing them with the necessary furniture was carried out in a timely manner. At the Night`s school, there were 75 students studying with two groups that liked their cultural level. ${ }^{2}$

By December 1927, according to the data of the Peqin Sub-Prefecture, the number of schools and the number of pupils in it, presented by the School Directorate Plotor ${ }^{3}$ resulted: Peqin Plotor School consisted of 6 cadres, and 103 students of registered students, from which they continued the 88-90 school regularly. The Women's School consisted of 2 rankings, registered 47 girls, and continued to study 30-35 girls regularly. The school of Rrogozhina had 1 class and 33 pupils, of whom 27 students regularly studied. The School of Gjuzejt consisted of 1 class, with 49 students, of whom 16-20 pupils frequented regularly. The School of Uruçaj could not be opened after 9 Heads of the County of this school had not been able to collect the necessary aids for repairing the school building and its furniture in time. This school opened in March 1928 and 12 students were enrolled. ${ }^{4}$

In the District of Elbasan and in the Sub-Prefectures of Peqin and Gramsh regarding the non-attendance by the school students, it was informed that strict measures were taken that would penalize their parents. This was an obligatory way to increase the attendance of students in schools.

In 1928 in support of the education of Elbasan, the local population contributed and collected financial assistance. The collected amount of 252.56 gold francs, of which one part was handed over to the Directorate of Normal School.5 During this year, a commission of 12 members for the collection of aids for the reorganization of the Internat (dormitory-R.M., E.S.) was established in the Gramsh Prefecture, the Commission collected an amount of 9027 gold francs. The establishment of the Internat building was set up in an area near Devoll, 200 meters from the Gramsh

\footnotetext{
${ }^{1}$ Central Archive. of R. Al., F. 271-Elbasan Prefecture, D. 70, page 7, 1927

2 Central Archive. of R. Al., F. 271-Elbasan Prefecture, D. 173, pp. 2-6, 1927

${ }^{3}$ Central Archive. of R. Al., F. 271-Elbasan Prefecture, D. 42, p. 28, 1928

${ }^{4}$ Central Archive. of R. Al., F. 271-Elbasan Prefecture, D. 45, p. 28, 1928

${ }^{5}$ Central Archive. of R. Al., F. 271-Elbasan Prefecture, D. 116, p. 33, 1928
} 
Government Building. ${ }^{1}$ In 1927-1928, primary dormitories were opened in Elbasan's Bërzeshtë. ${ }^{2}$ In these years an important role was devoted to the fight against illiteracy, which continued to exist at high levels in the prefecture and in the country.

At the end of this paper we conclude that Albania and Elbasan as an integral part and as one of its prefectures during the period of Republican Government from 1925 to 1928 in the field of education marked achievements but not enough in the delivery of primary education and the middle one. During these years in the country, important steps were taken in the implementation of Reforms in the field of education, which consisted of changing the organizational structure of the school, the programs, the connection of the theory with the practice, On the basis of these reforms in the area of Elbasan opened new schools, dormitories, improved education in the existing schools, schools that did not work with the educational framework, schools of night classes were opened. Despite the steps taken and the attention paid to by the governing policies, despite the efforts of encouragement and development, it should be noted that the educational situation remained again at satisfactory levels. The difficult financial situation in the country was a decelerating factor in terms of investments in this sector. But Elbasan and peoples of Elbasan, in spite of the difficulties that they had in everyday life, united their efforts, and unleashed their generosity, to give life and development to education in their area, despite the difficult economic situation in which they lived. Through it (education) the Elbasan's children could absorb the oxygen of knowledge and through it serve in the future with all their potentials Elbasan of Albania.

\section{Bibliography:}

[1] Central Archive. of R. Sh., F. 271-Elbasan Prefecture:

- File 161, 1925

- File 194, 1925

- File 152, 1925

- File 116, 1927

- $\quad$ File 42, 1927

- $\quad$ File 70,1927

- File 119, 1927

- File 173, year 1927

- $\quad$ File 42, 1928

\footnotetext{
${ }^{1}$ Central Archive. of R. Al., F. 271-Elbasan Prefecture, D. 66, page 2, 1928

2"10 years Kingdom 1928-1938", Tirana 1 September 1938, page 153
} 
- $\quad$ File 45, 1928

- File 116, 1928

- $\quad$ File 66, 1928

[2] Albanian Academy of Sciences, "The History of the Albanian People," Vol. III, Toena 2007 Official Gazette, Tirana, 6 November 1927

[3] "10 years Kingdom 1928-1938", Tirana 1 September 1938

[4] "Telegraph" newspaper, Tirana, Sunday, March 6, 1927

[5] Magazine "Normalisti" Elbasan, Nr. 3, May 1929

[6] Musa Tafa, "Normalist-on the occasion of the 50th anniversary of the opening of the Normal School (1909-1959), Elbasan 1959

[7] "Normality in Tradition", Elbasan 1995

[8] Teki Selenica, "Albania in 1927", Tirana 1928 